\title{
PENGARUH PENGGUNAAN SELEBRITI DALAM IKLAN TERHADAP MINAT BELI KONSUMEN
}

\author{
Asmai Ishak \\ Fakultas Ekonomi Universitas Islam Indonesia \\ e-mail: ishaka@fe.uii.ac.id
}

\begin{abstract}
This study investigates the effectiveness of the celebrity's use in the advertisement. It, specifically, analyses the effect of credibility of the celebrity on the attitude toward the advertisement and the purchase intention. By using structural equation modelling with one congeneric measurement approach, this study indicates that from three dimensions of celebrity's credibility, only attractiveness does not have significant influence on the attitude toward the ads. The other two dimensions that are trustwothiness and expertise have positively and significantly affect the attitude toward the ads which in turn enhances significantly the purchase intention. Additonally, it also finds that the effect of attitude toward the ads on purchase intention is so small indicating there some factors affecting the purchase intention
\end{abstract}

Keywords: credibility of the celebrity, attractiveness, trusworthiness, expertise

\section{PENDAHULUAN}

Banyak organisasi bisnis menganggap iklan sebagai investasi dari pada biaya. Iklan merupakan metode komunikasi yang efektif untuk mencapai audien yang luas (Rex, 1997). Iklan juga dipandang sebagai metode untuk membedakan produk perusahaan dari pesaingnya (Kalra \& Goodstein, 1998), dan menciptakan citra dan daya tarik merek atau organisasi (Rex, 1997). Iklan dapat menciptakan kesadaran konsumen terhadap sebuah produk atau merek, dan memungkinkan produk yang "sebetulnya kurang disukai" untuk lebih diperhitungkan (Terhune \& Steinberg, 2003). Persepsi konsumen terhadap sebuah produk yang negatif dapat berubah menjadi positif setelah mereka melihat iklan produk tersebut. Hertzendorf (1993) berpendapat bahwa kualitas dari sebuah produk ditentukan oleh kemampuan manajer perusahaan tersebut dalam mempresentasikan produknya dibenak konsumennya.
Banyak manajer yang meyakini bahwa iklan juga mampu meningkatkan loyalitas konsumen (Guiltinan, Paul and Madden, 1997). Hanung Budya, Manajer Pemasaran PT. Pertamina, sependapat dengan keyakinan tersebut, dan menetapkan "mempertahankan loyalitas pelanggan" sebagai salah satu tujuan dari iklan yang PT. Pertamina (Sinar Harapan, 2002). Hasil penelitian menunjukkan fakta yang kurang mendukung pendapat tersebut. Datta (2003) menunjukkan bahwa iklan mempunyai pengaruh yang kecil terhadap loyalitas pelanggan. Namun demikian, dia masih tetap percaya bahwa iklan masih berpengaruh terhadap pembelian produk yang diiklankan.

Pada dasarnya, tujuan utama dari sebuah iklan adalah untuk membuat produk atau merek dikenal, dan untuk membantu terciptanya kesadaran instan (Joshi, 2003). Penggunaan selebriti dalam iklan dapat membantu pencapaian tujuan tersebut. Selebriti diyakini lebih menarik dan menggugah dari pada penggunaan orang biasa 
dalam mempengaruhi calon konsumen Dengan demikian, selebriti dapat membantu perusahaan untuk meningkatkan efektifitas iklannya mengingat mereka dapat menciptakan kesadaran konsumen yang pada akhirnya meningkatkan minat beli konsumen (Kamins 1990; Ohanian 1991; Goldsmith, Lafferty, and Newel, 2000; Daneshvary and Schwer, 2000). Hal ini membuat banyak perusahaan yang memanfaatkan pesona selebriti untuk efektivitas pesan iklannya, meskipun perusahaan harus mengeluarkan biaya besar untuk kontrak dengan mereka setiap tahunnya (O'Mahony and Meenaghan, 1997/1998; Hsu and McDonald, 2002).

Selibriti yang sering muncul dalam acara TV komersial dapat menciptakan interaksi antara dia dengan audiennya yang pada akhirnya membentuk hubungan sosial yang imajiner (Alperstein, 1991). Hubungan imajiner tersebut, selanjutnya, memunculkan kecenderungan audien untuk mengaitkan kegiatan sehari-hari sang selebriti dengan produk yang diiklankan. Kondisi semacam ini membantu pemasang iklan dalam membangun citra produk atau merek dalam memori audien. Hal ini mengakibatkan banyak manajer pemasaran yang lebih suka untuk menggunakan selebriti daripada orang biasa sebagai endorser dalam meningkatkan perasaan suka terhadap iklan dan minat beli terhadap produk yang diiklankan.

Banyak faktor yang sebaiknya dipertimbangkan oleh perusahaan yang akan menggunakan selebriti dalam iklan produknya. Penggunaan selebriti tersebut kadangkala mampu meningkatkan penjualan, tetapi adakalanya gagal dalam mempromosikan produk. Namun demikian secara umum penggunaan selebriti sebagai endorser telah terbukti sangat efektif dalam pengiklanan beberapa produk. Ohanian (1991) menekankan bahwa kredibilitas selebriti mempunyai peranan yang penting dalam menciptakan persepsi yang baik terhadap produk atau merek yang diklankan, dan dalam meningkatkan penjualan. Oleh karena itu, penelitian ini bertujuan untuk menganalisa pengaruh kredibilitas selebriti terhadap sikap terhadap iklan dan minat beli konsumen.

\section{KAJIAN PUSTAKA DAN PENGEMBANGAN HIPOTESA Kredibilitas Selebriti}

Selebriti adalah orang yang terkenal di masyarakat. Dia bisa seorang bintang film, bintang sinetron, model, pelawak, presenter, olahragawan, ilmuwan, bisnisman, politikus, penyanyi, dan orang-orang terkenal lainnya (O'Mahony and Meenaghan, 1997/1998; Hsu and McDonald, 2002). Alasan pemakaian selebriti sebagai bintang iklan karena dipercaya dapat meningkatkan attention saat stimulus diekspose dan proses recall saat konsumen mengasosiasikan dengan jaringan semantik dalam memori (Ohanian, 1991; Stafford, Stafford, and Day, 2002).

Fakta empiris menunjukkan bahwa penggunaan selebriti dalam iklan merupakan metode yang efektif untuk komunikasi yang persuasif (Hsu \& McDonald, 2002). Selebriti lebih disukai dari pada orang biasa dalam menyampaikan pesan iklan (Kamins, 1989). Mereka mempunyai citra spesifik yang dapat membedakannya dari orang biasa. Hal ini mengakibatkan banyak orang memberi respek dan seringkali mengadopsi penampilan dan gaya hidup selebriti yang dikaguminya. Oleh karena itu, iklan yang menggunakan selebriti sebagai pembawa pesan mudah diterima oleh para penggemear dan pengagum sang selebriti. Manajer berkeyakinan bahwa pesan iklan yang disampaikan oleh selebriti sebagai orang yang dikenal dalam masyarakat menghasilkan perhatian yang tinggi (Ohanian, 1991). Tom, Clark, Elmer, Grech, Masetti Jr., and Sandhar, (1992) menambahkan selebriti dapat membuat pesan yang disampaikan mudah diingat oleh audiennya. 
Namun demikian, penggunaan selebriti dalam iklan bisa menimbulkan masalah. Adakalanya penggunaan selebriti tersebut dapat menjadi bumerang bagi perusahaan. Seringkali kehidupan pribadi dan perilaku sang selibriti mempengaruhi persepsi audien terhadap citra produk atau merek yang diiklankan. Umpamanya, ketika selebriti sebagai endorser terlibat kasus narkoba atau kasus kriminal lainnya, maka hal ini akan berakibat buruk pada citra produk atau merek yang diiklankan. Jika itu terjadi maka perusahaan langsung tidak lagi menayangkan iklan tersebut dan memutus hubungan kerja dengan sang selebriti. Permasalahan lain terjadi ketika popularitas selebriti melebihi citra produk yang diiklankan. Walker and Langmeyer (1992) menyatakan bahwa kesuksesan penggunaan selebriti sangat tergantung kesesuaian antara sang selibriti dengan produk yang diiklankan. Hal ini sesuai dengan pendapat Kamins (1990) yang menyatakan bahwa sebuah iklan akan lebih efektif jika pembawa pesan dan produk yang diiklankan memiliki kesamaan atribut. Namun demikian, terlepas dari beberapa permasalahan tersebut, penggunaan selebriti sebagai pembawa pesan produk atau merek dapat memegang peran penting dalam membangun ekuitas merek dan memperkuat posisi saing merek, jika perusahaan tersebut mengelola penggunaan selebriti tersebut secara benar (Till, 1998).

Perusahaan menggunakan selebriti sebagai endorser dikarenakan kredibilitas dan daya pikatnya (Goldsmith et. al., 2000; dan Kamins, 1990). Goldsmith et. al (2000) menyatakan bahwa kredibilitas endorser mempunyai pengaruh yang paling kuat pada audien. Secara umum kredibilitas endorser bisa diartikan sebagai suatu karakteristik positif komunikator yang berpengaruh terhadap penerimaan suatu pesan oleh receiver (Stafford et. al. 2002). Kredibiltas selibriti merupakan faktor penting untuk meyakinkan efektifitas penyampaian pesan iklan. Peng- gunaan selebriti dalam iklan memberikan manfaat yang lebih nyata dibandingkan dengan teknik promosi yang lain (Wheeler, 2003). Selebriti yang kredibel dapat menghasilkan perubahan yang positif, mendorong perubahan perilaku, meningkatkan kemampuan iklan untuk mempengaruhi audien, dan mengurangi terjadinya counterarguments (Avery, 1998).

Penelitian mengenai kredibilitas bintang iklan telah menunjukkan bahwa dalam banyak situasi kredibilitas pembawa pesan yang tinggi lebih efektif daripada yang kurang kredibel. Kredibilitas bintang iklan yang tinggi juga telah ditemukan menghasilkan perubahan sikap yang lebih positif dibandingkan dengan yang kurang kredibel (Lafferty and Goldsmith, 1999). Kredibilitas bintang iklan menjadi variabel yang mendahului (antecedent) dalam Sikap Terhadap Iklan dan Sikap Terhadap Merek (Fishbein and Ajzen, 1975; Goldberg and Hartwick, 1990). Goldsmith et. al. (2000) menunjukkan bahwa kredibilitas bintang iklan berpengaruh secara positif terhadap Sikap Terhadap Iklan.

Ohanian (1990) mengidentifikasi tiga dimensi yang membentuk kredibilitas selebriti: attractiveness (daya pikat), trustworthiness (tingkat kepercayaan), dan expertise (keahlian). Selanjutnya dia menjelaskan bahwa ketiga dimensi tersebut, baik secara mandiri atau bersama-sama, mempunyai kontribusi dalam mempengaruhi sikap audien terhadap iklan dan minat beli. Penelitian ini menggunakan ketiga dimensi tersebut untuk mengukur kredibilitas selebriti. Uraian berikut menjelaskan dimensi-dimensi tersebut secara detil.

\section{Attractiveness (Daya Pikat)}

Solomon, Ashmore, and Longo (1992) mengatakan bahwa spokesperson yang attractive lebih efektif dibandingkan dengan yang tidak attractive dalam iklan dan promosi. Peningkatan penggunaan selebriti 
sebagai endorsers dari produk, jasa dan kasus-kasus sosial, attractiveness (daya pikat) telah menjadi suatu dimensi penting dari kredibilitas sumber (Patzer, 1983; Ohanian, 1991). Daya pikat fisik akan cenderung memberikan dampak persuasi bagi orang yang melihatnya (Louie and Obermiller, 2002; Stafford et. al., 2002). Studi empiris menunjukkan bahwa selibriti lebih mempunyai daya pikat dibandingkan dengan non-selebriti (Rex, 1997). Endorser yang mempunyai daya pikat lebih mampu mendorong munculnya niat beli audiennya dari pada yang kurang mempunyai daya pikat. (Kahle and Homer, 1985; dan Rex, 1997). Daya pikat fisik (cantik atau tampan) selebriti dapat mempengaruhi opini audien dalam mengevaluasi produk (Goldsmith et. al., 2000).

Namun demikian, masih belum ada kesepakatan yang utuh diantara para peneliti berkenaan dengan pengaruh daya pikat ini. Seperti yang dikemukan oleh Ohanian (1991) bahwa dia tidak menemukan pengaruh yang signifikan dari daya pikat terhadap minat beli. Dia menambahkan bahwa ketiadaan pengaruh tersebut sangat dimungkinkan karena responden menganggap bahwa semua selebriti dalam iklan yang sedang diteliti semuanya mempunyai daya pikat. Sebaliknya Rex (1997) berpendapat bahwa kegagalan daya pikat fisik dalam komunikasi persuasif lebih banyak disebabkan oleh manipulasi daya pikat yang berlebihan. Hal ini berakibat pada hasil penelitian yang menunjukkan tidak ada perbedaan persepsi responden pada daya pikat antara sumber kredibilitas yang tinggi dan yang rendah.

Terlepas dari perbedaan pendapat diantara para pakar, daya pikat masih diyakini dapat meningkatkan perasaan suka terhadap iklan dan atau minat beli konsumen. Hal ini dikemukan oleh Kamin (1990) bahwa daya pikat fisik selebriti dapat meningkatkan citra produk selama karakteristik produk tersebut sesuai dengan citra selebritinya. Dia juga menemukan bahwa daya pikat selebriti berpengaruh positif terhadap kredibilitas sang selebriti sebagai pembawa pesan dan sikap terhadap iklan. Konsumen cenderung membentuk stereotypes atau meniru bintang iklan dengan daya pikat fisik tersebut, dan sebagai tambahan, penelitian telah menunjukkan bahwa daya pikat fisik komunikator lebih sukses dalam merubah kepercayaan daripada komunikator yang tidak atraktif. Aristoteles mengatakan: "Beauty is greater recommendation than any letter of introduction" (O’Mahony and Meenaghan, 1997/1998). Berdasarkan uraian diatas peneliti membuat hipotesis sebagai berikut:

$\mathrm{H}_{1}$ : Attractiveness berpengaruh secara positif terhadap Sikap Terhadap Iklan

\section{Trustworthiness (Dapat Dipercaya)}

Trustworthiness mengacu pada kepercayaan konsumen kepada sumber untuk memberikan informasi dengan cara yang obyektif dan jujur (Avery, 1998; dan Ohanian, 1990). Trustworthiness atau sifat bisa dipercaya merupakan karakteristik kunci bagi efektivitas pembawa peasan. Banyak dari kita akan lebih percaya pada teman yang dapat dipercaya dari pada seorang tenaga penjualan yang meskipun lebih memiliki pengetahuan tentang produk, tetapi kita ragu untuk membeli karena belum ada kepercayaan terhadapnya. Konsumen dalam hal ini melihat bahwa terdapat potensi konflik kepentingan pada diri tenaga penjualan tersebut sehingga apapun pendapatnya dianggap memihak kepada produk atau perusahaan penghasil produk. Oleh karena itu, Ohanian (1990) menganjurkan agar perusahaan tidak memilih selebriti untuk iklan produknya jika selebriti tersebut mempunyai "expertise dan trusworthiness" secara bersamaan. Kalau expertise mengacu pada tingkat pengetahuan tentang subjek, maka trustworhiness merujuk pada kejujuran dan sifat bisa dipercaya dari sumber (Goldsmith 
et. al. 2000; Stafford et. al. 2002; O’Mahony and Meenaghan, 1997/1998). Lebih lanjut Ohanian (1990) mengemukakan bahwa sebuah pesan iklan dapat merubah sikap audiennya jika mereka menganggap bahwa pembawa pesan dapat dipercaya. Oleh karena itu peneliti membuat hipotesa sebagai berikut:

$\mathrm{H}_{2}$ : Trusworthiness berpengaruh secara positif terhadap Sikap Terhadap Iklan

\section{Expertise (Keahlian)}

Expertise (keahlian) didefinisikan sebagai suatu tingkatan dimana komunikator dipersepsikan sebagai sumber dengan pernyataan yang valid dan dipercaya memberikan opini yang obyektif tentang subjek (Ohanian, 1991). Hal ini merujuk kepada bahwa pengetahuan komunikator tampak sangat mendukung atas pernyataan yang disampaikan dalam iklannya (Avery, 1998). Sebagai contoh atlit, dokter, dan pengacara adalah endorsers yang tepat untuk produk dan jasa yang berhubungan dengan bidang profesi mereka (O’Mahony and Meenaghan, 1997/1998).

Study empiris menggaris bawahi tentang pentingnya aspek expertise bagi pembawa pesan (Ohanian, 1991 dan Rex, 1997). Menon, Boone, and Rogers (2001) dan Ohanian (1991) bahkan menemukan dari ketiga sumber kredibilitas selebriti hanya expertise yang mempunyai pengaruh signifikan terhadap minat beli. Hal ini menunjukkan bahwa penggunaan expertise dari selibriti dapat menstimulir perubahan sikap konsumen.

Konsumen mempersepsikan produk atau merek yang diiklankan oleh selebriti yang mempunyai citra expertise dan trustworthiness sebagai produk atau merek yang kredibel (Johnston, 2001). Hal ini memberikan konsumen sebuah referensi dalam membandingkan attribute produk dan memudahkan mereka dalam memilih produk yang akan dibelinya (Ohanian, 1991). Dengan mengacu kepada temuan Goldsmith et. al. (2000) bahwa kredibilitas bintang iklan berpengaruh secara positif terhadap Sikap Terhadap Iklan, maka peneliti membuat hipotesa sebagai berikut:

$\mathrm{H}_{3}$ : Expertise berpengaruh secara positif terhadap Sikap Terhadap Iklan

\section{Sikap Terhadap Iklan}

Biehal, Stephen, and Curlo (1992) mendefinisikan sikap terhadap iklan (attitude toward the $A d$ ) sebagai suatu kecenderungan untuk merespon dengan cara yang baik atau tidak baik suatu stimuli iklan tertentu dalam suatu situasi eksposur tertentu. Sikap terhadap iklan merupakan faktor yang penting untuk meneliti efektifitas penggunaan selebriti dalam iklan. Menon et. al. (2001) mengungkapkan bahwa ada keterkaitan antara kredibilitas dan pengetahuan dengan sikap terhadap iklan. Pesan iklan yang disampaikan oleh endorser yang kredibel dapat menumbuhkan perasaan suka dan percaya terhadap iklan tersebut dan meningkatkan persepsi positif konsumen terhadap produk yang diiklankan. Kamins, Brand, Hoeke, and Moe (1989) menemukan bahwa terdapat hubungan langsung antara sikap terhadap iklan dengan efektifitas iklan yang diukur dengan minat beli.

Banyak studi empiris yang menunjukkan adanya pengaruh langsung dari Sikap Terhadap Iklan terhadap Niat Beli konsumen. Mehta dan Purvis (1997), dengan pendekatan Advertising Response Modeling (ARM), mengukur efektivitas periklanan yang secara eksplisit menunjukkan keterkaitan langsung antara Sikap Terhadap Iklan dan Niat Beli. Mereka menemukan bahwa Sikap Terhadap Iklan berpengaruh terhadap Niat Beli. Mereka melaporkan pengaruh sikap terhadap iklan pada Niat Beli signifikan untuk iklan yang informasional dan yang transformasional. Temuan ini diperkuat oleh Goldsmith et. al. (2000) melalui suatu model eksperimen yang menun- 
jukkan bahwa Sikap Terhadap Iklan secara langsung berpengaruh pada Niat Beli untuk produk yang familiar dan yang unfamiliar. Berdasarkan uraian diatas maka peneliti menghipotesakan bahwa:

$\mathrm{H}_{4}$ : Sikap Terhadap Iklan berpengaruh secara positif terhadap Niat Beli

\section{Minat Beli}

Meramalkan perilaku pembelian konsumen dimasa yang akan datang sangatlah penting dalam perencanaan pemasaran. Perilaku pembelian konsumen yang akan datang dapat diukur dari niat berperilaku, yaitu suatu keinginan yang kuat untuk terlibat dalam perilaku tertentu. Niat berperilaku adalah metode yang paling baik untuk memprediksi perilaku individu (Biehal, et. al., 1992; Bosnjak, Obermeir, and Tuten, 2006). Theory of Reasoned Action (TRA) mengasumsikan bahwa perilaku konsumen ditentukan oleh niat berperilaku konsumen. Pengukuran niat berperilaku dilakukan tepat sebelum pembelian dilakukan dan hal inilah yang membuat pengukuran niat berperilaku pada kasus-kasus tertentu menjadi kurang akurat (Fazekas, Senn, and Ledgerwood, 2001).
Belk (1985) mengungkapkan bahwa ada beberapa faktor yang dapat melemahkan hubungan antara keinginan berperilaku dan perilaku yang diamati. Hal ini meliputi: penghalang waktu, kejadian lingkungan yang tak terduga, konteks situasional yang berbeda, dan informasi baru. Dari beberapa faktor tersebut penghalang waktu merupakan faktor utama yang dapat melemahkan keakuratan prediksi pengukuran niat berperilaku, mengingat sebagaimana faktor kognitif lainnya niat berperilaku dapat berubah sepanjang waktu. Semakin lama tenggang waktu yang diberikan, semakin banyak pengaruh lingkungan yang akan mengubah kepercayaan dan sikap konsumen. Disamping itu dari tenggang waktu yang ada juga akan memungkinkan konsumen menerima informasi baru yang kemudian akan merubah konteks situasi lingkungan yang berbeda antara saat pengukuran dengan situasi saat perilaku dinyatakan.

\section{Kerangka Konseptual Penelitian}

Berdasarkan hipotesa dan hubungan antar variabel yang telah diuraikan di atas dapat digambarkan kerangka konseptual penelitian ini sebagai berikut:

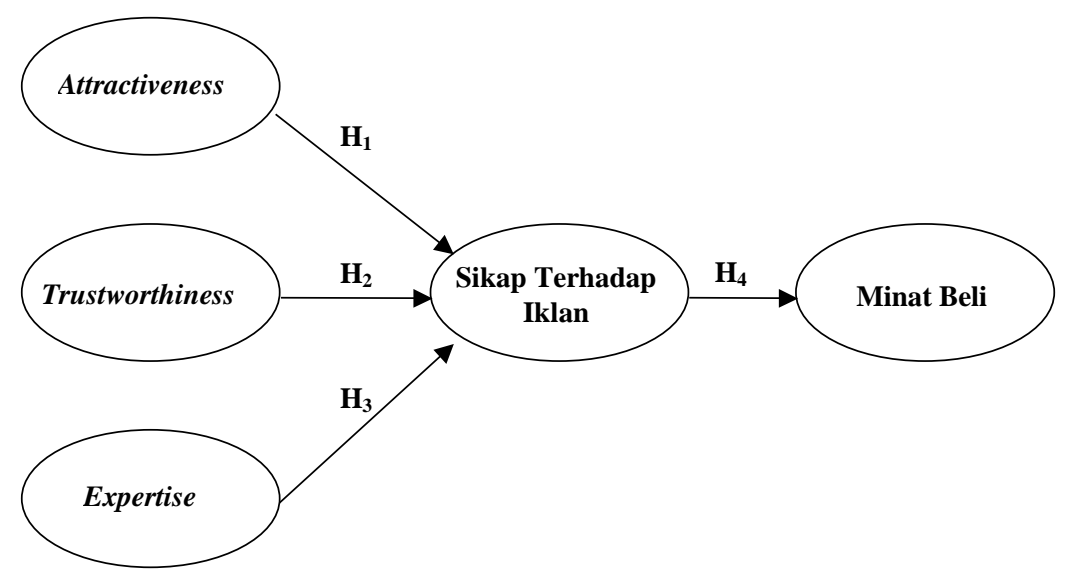

Gambar 1: Kerangka Konseptual Penelitian 


\section{METODOLOGI PENELITIAN}

Mengingat penelitian ini bertujuan untuk mengukur efektifitas kredibilitas selebriti dalam mendorong niat beli konsumen, maka penelitian ini menggunakan iklan salah satu sepeda motor yang termasuk dalam kelompok tiga besar di pasar Indonesia sebagai obyek penelitian. Pemilihan obyek penelitian ini dimaksudkan untuk memudahkan responden dalam menjawab daftar pertanyaan karena selain merek sepeda motor tersebut sudah dikenal oleh masyarakat Indonesia, selebriti yang membintangi iklannya juga terkenal.

Populasi penelitian ini adalah setiap orang yang mengenal bintang iklan yang dipakai dalam instrumen penelitian ini. Mengingat popoulasi penelitian ini sangat luas, maka peneliti membatasi daerah penelitian ini didaerah seputar Kampus Fakultas Ekonomi Universitas Islam Indonesia. Pemilihan sample sebanyak 170 dilakukan dengan menggunakan non-probability sampling method. Selain itu pendekatan purposive sampling juga digunakan untuk meyakinkan bahwa responden penelitian ini benar-benar mengenali bintang iklan yang dipakai dalam penelitian ini. Dari 170 responden yang terlibat dalam penelitian ini, hanya 148 yang dipertimbangkan untuk diikutkan dalam analisa. Sedangkan 22 responden yang lain tidak disertakan dalam analisa karena respon yang diberikan tidak lengkap.

Pengumpulan data penelitian dilakukan dengan menggunakan kuesioner yang merupakan pengembangan dari istrumen penelitian yang telah dipergunakan oleh Ohanian (1990) dan Menon et. al. (2001). Secara lebih rinci, pengukuran variable Attractiveness (lima item), Trustworthiness (lima item), dan Expertise (lima item) diadaptasi dari Ohanian (1990), sedangkan Sikap Terhadap Iklan (lima belas item) dan Minat Beli (tiga item) diadaptasi dari Menon et. al. (2001). Semua variabel tersebut diukur menggukan 7 (tujuh) skala Likert, dimana 1 menunjukkan sangat tidak setuju dan 7 menandakan sangat setuju. Selain pertanyaan mengenai kelima variable dan jati diri resonden, peneliti juga menambah satu pertanyaan yang khusus dikembangkan untuk penelitian ini yaitu berkenaan dengan pertimbangan seandainya responden tersebut akan membeli sepeda motor yang diiklankan apakah karena merek sepeda motor tersebut, atau karena bintang iklannya, atau karena keduanya. Berdasarkan uji kuesioner kepada 35 reponden, yang tidak disertakan pada analisa data, menunjukkan bahwa semua item pertanyaan valid dan reliabel dalam mengukur variabel penelitian ini. Hasil uji validitas dan reliabilitas secara detil dapat dilihat pada Tabel 1 berikut ini. 
Tabel 1: Hasil Uji Validitas dan Reliabilitas Instrumen Penelitian

\begin{tabular}{lccc}
\hline \multicolumn{1}{c}{ Vareabel/ Item pertanyaan } & $\begin{array}{c}\text { Corrected Item- } \\
\text { Total Correlation }\end{array}$ & $\begin{array}{c}\text { Cronbach's } \\
\text { Alpha }\end{array}$ & Status \\
\hline $\begin{array}{l}\text { Attractiveness } \\
\text { Penampilan Bintang iklan tersebut menarik }\end{array}$ & 0,635 & 0,846 & $\begin{array}{c}\text { Reliabel } \\
\text { Valid }\end{array}$ \\
$\begin{array}{l}\text { Penampilan Bintang iklan tersebut berkelas } \\
\text { Bintang iklan tersebut tampan }\end{array}$ & 0,700 & Valid \\
Penampilan Bintang iklan tersebut elegan & 0,552 & Valid \\
Penampilan Bintang iklan tersebut seksi & 0,785 & Valid \\
$\quad$ Trustworthiness & 0,622 & Valid \\
Bintang iklan tersebut dapat diandalkan & 0,382 & Reliabel \\
Bintang iklan tersebut jujur dalam menyam- & 0,405 & Valid \\
paikan pesan iklan & & & Valid \\
Bintang iklan tersebut konsisten dalam pen- & 0,655 & & Valid \\
yampaiannya & & & Valid \\
Bintang iklan tersebut tulus dalam penyam- & 0,558 & & Valid \\
paiannya & & & Reliabel \\
Bintang iklan tersebut dapat dipercaya & 0,643 & Valid \\
$\quad$ Expertise & & 0,802 & Valid \\
Bintang iklan tersebut seorang ahli & 0,675 & & Valid \\
Bintang iklan tersebut berpengalaman & 0,478 & & Valid \\
Bintang iklan tersebut berpengetahuan luas & 0,439 & & Valid \\
Bintang iklan tersebut berkualitas & 0,743 & & \\
Bintang iklan tersebut terampil & 0,636 & & \\
\hline
\end{tabular}


Tabel 1: Lanjutan

\begin{tabular}{|c|c|c|c|}
\hline Vareabel/ Item pertanyaan & $\begin{array}{l}\text { Corrected Item- } \\
\text { Total Correlation }\end{array}$ & $\begin{array}{l}\text { Cronbach's } \\
\text { Alpha }\end{array}$ & Status \\
\hline Sikap Terhadap Iklan & & 0,898 & Reliabel \\
\hline Iklan tersebut dapat dipercaya & 0,555 & & Valid \\
\hline Iklan tersebut nampak meyakinkan & 0,668 & & Valid \\
\hline Iklan tersebut nampak kredibel & 0,443 & & Valid \\
\hline Iklan tersebut nampak jujur & 0,564 & & Valid \\
\hline Iklan tersebut tidak meragukan & 0,622 & & Valid \\
\hline Iklan tersebut bermanfaat & 0,484 & & Valid \\
\hline Iklan tersebut menarik & 0,670 & & Valid \\
\hline Iklan tersebut bagus (baik) & 0,661 & & Valid \\
\hline Iklan tersebut bercitarasa & 0,464 & & Valid \\
\hline Iklan tersebut dapat dinikmati & 0,638 & & Valid \\
\hline Iklan tersebut tidak membosankan & 0,717 & & Valid \\
\hline Iklan tersebut berkesan moderen & 0,589 & & Valid \\
\hline Iklan tersebut berkesan seksi & 0,474 & & Valid \\
\hline Pesan Iklan tersebut kuat & 0,445 & & Valid \\
\hline Pesan Iklan tersebut efektif & 0,722 & & Valid \\
\hline Minat Beli & & 0,765 & Reliabel \\
\hline $\begin{array}{l}\text { Saya akan mencari tahu lebih lanjut mengenai } \\
\text { produk ini. }\end{array}$ & 0,563 & & Valid \\
\hline $\begin{array}{l}\text { Saya akan mempertimbangkan untuk membeli } \\
\text { produk ini. }\end{array}$ & 0,759 & & Valid \\
\hline $\begin{array}{l}\text { Saya sungguh-sungguh ingin membeli produk } \\
\text { ini. }\end{array}$ & 0,534 & & Valid \\
\hline
\end{tabular}

\section{HASIL PENELITIAN DAN PEMBAHASAN}

Seperti yang telah dijelaskan di depan bahwa responden yang terlibat dalam penelitian dan layak untuk analisa lebih lanjut berjumlah 148 orang. Dari responden yang terlibat tersebut sebagian besar $(57 \%)$ adalah perempuan dan sisanya laki-laki. Sebagian besar $(83 \%)$ dari mereka berusia antara 16 sampai 25 tahun dan sisanya berusia 26 sampai 55 tahun lebih. Dalam pekerjaan, lebih dari tiga per empat responden adalah mahasiswa sedangkan sisanya bekerja sebagai pegawai negeri $(9,3 \%)$, pegawai swasta $(7,3 \%)$ dan wiraswasta $(8 \%)$.
Selanjutnya, peneliti menggunakan Structural Equation Modelling (SEM) dalam menanalisa kerangka konseptual penelitian ini. Secara khusus peneliti menggunakan program LISREL 8.30 dan pendekatan onecongeneric measurement models yang dikembangkan oleh Holmes-Smith and Row (1994) untuk menguji hipotesa penelitian. Hal ini disebabkan karena indikator ( $o b-$ served variables) dari penelitian ini bersifat ordinal. Variabel seperti ini harus dianalisa berdasarkan polychoric or polyserial correlation matrix yang menggunakan prosedur weighted least squares estimate yang selanjutnya membutuhkan asymptotic covariance 
matrix. Preosedur ini harus dilakukan tidak hanya untuk mengeliminasi bias estimasi (Joreskog and Sorbom, 1996a), tetapi juga untuk mengatasi data yang tidak normal (Holmes-Smith and Rowe, 1994). Namun demikian matrik tersebut, khususnya, asymptotic covariance matrix memerlukan data yang sangat besar. Joreskog and Sorbom (1996b) menyatakan bahwa jumlah sample minimal yang dibutuhkan untuk matrik ini sama dengan $k(k-1): 2$, dimana $k$ adalah jumlah indikator. Mengingat jumlah indikator penilitian ini adalah 33 (tiga puluh tiga) maka sample yang dibutuhkan seharusnya sebanyak 528 (lima ratus dua puluh delapan), hasil dari 33(33 - 1): 2, agar peneliti dapat menggunakan asymptotic covariance matrix.

Namun demikian, sample penelitian ini hanya berjumlah 148, yang berarti cukup jauh dari jumlah minimal yang dibutuhkan. Untuk mengatasi permasalahan ini, peneliti menggunakan pendekatan one-congeneric measurement models. Pendekatan ini merupakan salah satu cara untuk mengurangi jumlah indikator dengan cara menyatukan (composite) indikator tersebut. HolmesSmith and Rowe (1994) menyarankan bahwa indikator tersebut harus benar-benar reliable dan akurat dalam merepresentasikan konstruk, karena jika persyaratan ini tidak terpenuhi akan mengakibatkan composite scale yang dibentuk akan memiliki validitas yang rendah atau bahkan tidak valid. Oleh karenanya, mereka mensyaratkan indikator yang akan di composite minimal harus memiliki standardized factor loading sebesar 0,70 atau square multiple correlation $\left(\mathrm{R}^{2}\right)$ sebesar 0,50.

Berdasarkan persyaratan tersebut ada 11 (sebelas) indikator yang tidak disertakan dalam analisa selanjutnya karena standardized factor loading nya jauh dari 0,70 seperti yang disyaratkan. Indikator-indikator tersebut adalah ATTRACT5, TRUST1, TRUST3, EXPERT3, EXPERT4, AAD2, AAD6, AAD7, AAD12, AAD13, dan AAD14. Tabel 2 dibawah ini menunjukkan bahwa 22 (dua puluh dua) indikator valid untuk disertakan pada analisa selanjutnya, karena mereka memiliki standardized factor loading seperti yang disyaratkan oleh Holmes-Smith and Rowe (1994). Hanya indikator EXPERT5 yang mempunyai standardized factor loading dibawah 0,70 yaitu sebesar 0,69. 
Tabel 2: Rekapitulasi Hasil Uji Validitas dan Reliabilitas

\begin{tabular}{|c|c|c|c|c|}
\hline Nama Vareabel/Indikator & $\lambda_{i}^{*}$ & $\varepsilon_{i}^{*)}$ & $\begin{array}{l}\text { Composite Re- } \\
\text { liability }\end{array}$ & $\begin{array}{c}\text { Variance Ex- } \\
\text { tracted }\end{array}$ \\
\hline Attractiveness (ATRACT): & & & 0,86 & 0,61 \\
\hline ATTRACT1 & 0,79 & 0,38 & & \\
\hline ATTRACT2 & 0,83 & 0,32 & & \\
\hline ATTRACT3 & 0,74 & 0,46 & & \\
\hline ATTRACT4 & 0,77 & 0,41 & & \\
\hline Trustworthiness (TRUST): & & & 0,84 & 0,63 \\
\hline TRUST2 & 0,76 & 0,42 & & \\
\hline TRUST4 & 0,83 & 0,32 & & \\
\hline TRUST5 & 0,79 & 0,37 & & \\
\hline Expertise (EXPERT): & & & 0,81 & 0,59 \\
\hline EXPERT1 & 0,81 & 0,35 & & \\
\hline EXPERT2 & 0,79 & 0,37 & & \\
\hline EXPERT5 & 0,69 & 0,52 & & \\
\hline Sikap Terhdap Iklan (AAD): & & & 0,93 & 0,64 \\
\hline AAD1 & 0,7 & 0,51 & & \\
\hline AAD3 & 0,83 & 0,31 & & \\
\hline AAD4 & 0,73 & 0,46 & & \\
\hline AAD5 & 0,81 & 0,35 & & \\
\hline AAD8 & 0,84 & 0,29 & & \\
\hline AAD9 & 0,81 & 0,34 & & \\
\hline AAD10 & 0,84 & 0,3 & & \\
\hline AAD11 & 0,83 & 0,31 & & \\
\hline AAD15 & 0,77 & 0,41 & & \\
\hline
\end{tabular}

Tabel 2: Lanjutan

\begin{tabular}{lcccc}
\hline Nama Vareabel/Indikator & $\boldsymbol{\lambda}_{\mathbf{i}}{ }^{*}$ & $\boldsymbol{\varepsilon}_{\mathbf{i}}{ }^{*}$ & $\begin{array}{c}\text { Composite Re- } \\
\text { liability }\end{array}$ & $\begin{array}{c}\text { Variance Ex- } \\
\text { tracted }\end{array}$ \\
\hline Minat Beli (PI): & & & 0,87 & 0,70 \\
PI1 & 0,76 & 0,42 & & \\
PI2 & 0,73 & 0,46 & & \\
PI3 & 0,99 & 0,02 & & \\
\hline
\end{tabular}

${ }^{*} \lambda_{\mathrm{i}=}$ standardized factor loading; $\varepsilon_{\mathrm{I}=}$ error variance

Namun demikian indikator tersebut tetap disertakan dalam analisa karena koefisien standardized factor loading nya mendekati persyaratan minimalnya. Hal ini menunjukkan bahwa indicator tersebut. Selain itu, Tabel 1 tersebut menunjukkan bahwa semua vareabel penelitian ini reliabel untuk dianalisa lebih lanjut. Seperti yang dinyatakan oleh Holmes-Smith (2001) bahwa sebuah vareabel atau konstruk dikatakan reliabel jika mempunyai Composite
Reliabilty lebih besar dari 0,70 dan Variance Extracted lebih besar dari 0,50. Composite Reliabilty dari vareabel penelitian ini berkisar antara 0.81 sampai dengan 0,93, sedangkan Variance Extracted nya berkisar antara 0,59 sampai dengan 0,70.

Selanjutnya, dengan mengikuti langkah-langkah yang dikemukakan oleh Holmes-Smith and Rowe (1994), peneliti melakukan analisa struktural menggunakan Program LISREL 8.30 untuk menguji hi- 
potesa dari penelitian ini. Pengaruh vareable eksogen terhadap vareable endogen dan nilai $t$ dari masing-masing pengaruh nampak seperti pada Gambar 2 dibawah ini.

Nilai statistik dari model structural final diatas menunjukkan bahwa model tersebut sangat bagus (fit) dalam merepresentasikan data penelitian ini. Hal ini dibuktikan dengangan nilai $\chi^{2}$ sebesar 0,80 dengan probabilitas $84,9 \%$ yang berarti bahwa model tersebut mampu mereproduksi matrik populasi (population matrix). Fakta ini diperkuat oleh nilai RMSEA mendekati 0 (nol) dan nilai GFI, AGFI, serta CFI masing-masing sebesar 1 (satu). Selanjutnya, nilai Expected Cross Validation Index (ECVI) model penelitian ini sebesar 0,18. Nilai ini lebih rendah dari pada ECVI for the saturated model yang bernilai 0,20 . Hal ini menunjukkan bahwa model penelitian ini bisa direplikasi pada sampel yang serupa pada populasi yang sama.



Chi-Square $=0.80, \mathrm{df}=3, \mathrm{P}$-value $=0.84942, \mathrm{RMSEA}=0.000$

Gambar 2: Model Struktural Final (Nilai $t$ )

Tabel 3: Ringkasan Pengujian Hipotesa

\begin{tabular}{lcc}
\multicolumn{1}{c}{ Hipotesa } & $\begin{array}{c}\boldsymbol{\beta} \text { or } \boldsymbol{\gamma} \\
(\boldsymbol{t} \text {-value })\end{array}$ & Kesimpulan \\
\hline $\begin{array}{c}\mathbf{H}_{\mathbf{1}}: \text { Attractiveness berpengaruh secara positif terhadap Sikap } \\
\quad \text { Terhadap Iklan }\end{array}$ & $0,15(1,35)$ & Tidak Terbukti \\
$\begin{array}{l}\mathbf{H}_{\mathbf{2}}: \text { Trusworthiness berpengaruh secara positif terhadap Sikap } \\
\quad \text { Terhadap Iklan }\end{array}$ & $0,40(3,40)$ & Terbukti \\
$\begin{array}{l}\mathbf{H}_{\mathbf{3}}: \text { Expertise berpengaruh secara positif terhadap Sikap } \\
\quad \begin{array}{l}\text { Terhadap Iklan } \\
\mathbf{H}_{\mathbf{4}}: \text { Sikap Terhadap Iklan berpengaruh secara positif } \\
\text { terhadap Niat Beli }\end{array}\end{array}$ & $0,34(2,74)$ & Terbukti \\
\hline
\end{tabular}

$\beta=$ koefisien Beta; $\gamma=$ koefisien Gamma; $t$-value $=$ nilai $t$ 
Adapun signifikansi pengaruh antar vareabel dan pengujian hipotesa penilitian ini nampak seperti pada Tabel 3 di atas.

Berdasarkan Tabel 3 di atas, dari empat hipotesa yang dibangun pada penelitian ini hanya $\mathrm{H}_{1}$ yang tidak terbukti karena nilai $t$ nya kurang dari 1,96 , sementara hipotesa yang lain terbukti. Temuan ini menunjukkan bahwa secara umum selebriti yang dipergunakan dalam iklan sepeda motor tersebut cukup kredibel dalam meningkatkan perasaan suka responden terhadap iklan yang ditayangkan yang pada akhirnya berpengaruh terhadap minat beli responden.

Pengaruh Attractiveness terhadap Sikap Terhadap Iklan yang tidak signifikan menunjukkan bahwa daya pikat dari selibriti dalam penelitian ini kurang kuat untuk meningkatkan perasaan suka responden terhadap iklan yang dibintanginya. Hal ini bisa dimaklumi karena selebriti yang dipakai dalam penelitian ini adalah seorang pelawak yang dari segi penampilan fisik tidak semenarik bintang film atau sinetron. Sangat mungkin kegagalan daya pikat fisik dalam komunikasi persuasif disebabkan oleh manipulasi daya pikat yang berlebihan (Rex, 1997).

Namun demikian, kegagalan daya pikat dalam meningkatkan perasaan suka terhadap iklan bukan berarti bahwa selebriti yang dipakai dalam iklan sepeda motor tersebut tidak kredibel sebagai pembawa pesan iklan. Daya pikat (Attaractiveness) hanyalah salah satu dimensi yang mengukur kredibilitas selebriti. Masih terdapat dua dimensi yang lain untuk mengukur kredibilitas tersebut yaitu Trustworthiness dan Expertise. Penilitian ini membuktikan bahwa dua dimensi ini berpengaruh positif dan signifikan terhadap Sikap Terhadap Iklan. Temuan ini menunjukkan bahwa responden menganggap selebriti tersebut sebagai pembawa pesan yang dapat dipercaya dan mempunyai keahlian komunikasi dalam meningkatkan perasaan suka terhadap iklan. Hal ini sesuai dengan anjuran Ohanian
(1990) agar perusahaan memilih selebriti untuk iklan produknya yang mempunyai "expertise dan trusworthiness" secara bersamaan. Anjuran ini didukung oleh Johnston (2001) yang menyatakan bahwa konsumen mempersepsikan produk atau merek yang diiklankan oleh selebriti yang mempunyai citra expertise dan trustworthiness sebagai produk atau merek yang kredibel.

Meskipun salah satu dari ketiga dimensi kredibilitas tersebut tidak berpengaruh secara signifikan, tetapi secara keseluruhan kredibilitas selebriti sangat menentukan sikap responden terhadap iklan. Hasil penelitian ini menunjukkan koefisien diterminasi dari ketiga dimensi tersebut $\left(\mathrm{R}^{2}\right)$ sebesar 0,56 yang berarti ketiga dimensi tersebut mampu menjelaskan penyimpangan yang ada pada Sikap terhadap Iklan sebanyak $56 \%$.

Selanjutnya, hasil analisa peniltian ini menunjukkan bahwa Sikap Terhadap Iklan berpengaruh positif dan signifikan terhadap Minat Beli. Hasil ini konsisten dengan penelitian Kamins et. al. (1989) dan Mehta dan Purvis (1997) yang menemukan hubungan langsung antara sikap terhadap iklan dengan effektifitas iklan yang diukur dengan minat beli. Selain itu, hasil analisa menunjukkan bahwa koefisien diterminasi $\left(\mathrm{R}^{2}\right)$ sebesar 0,09 dengan kata lain Sikap Terhadap Iklan hanya mampu menjelaskan penyimpangan Minat Beli sebesar $9 \%$. Kecilnya koefisien ini menunjukkan bahwa masih banyak faktor lain yang menentukan minat beli konsumen yang perlu dipertimbangkan baik oleh peneliti maupun praktisi pemasaran.

Seperti yang telah diungkap pada bagian Metodologi Penenlitian, peneliti menambah satu pertanyaan yang sengaja dibuat untuk penelitian ini yaitu berkenaan dengan pertimbangan atau alasan yang mendorong mereka seandainya mereka membeli produk yang dipakai sebagai obyek penelitian ini. Hasilnya menunjukkan $47 \%$ citra 
merek/korporasi sebagai alasan utama, 9,3 $\%$ dipengaruhi oleh citra merek dan selibriti secara bersama-sama. Hanya 1,3\% responden yang lebih dipengaruhi oleh citra selibriti dalam membeli sepeda motor. Temuan ini merupakan jawaban atas temuan diatas bahwa kredibilitas dampak selebriti tidak terlalu besar dalam mendorong konsumen untuk melakukan pembelian. Pada saat yang bersamaan penelitian ini menunjukkan bahwa kredibilitas merek atau krebilitas korporasi lebih berpengaruh terhadap pembelian sebuah produk. Fakta ini mengindikasikan bahwa citra merek atau korporasi merupakan factor yang harus dipertimbangkan oleh peneliti dan praktisi pemasaran dalam mengevaluasi efektifitas iklan.

\section{PENUTUP}

Simpulan

Berdasarkan analisa dan pembahasan diatas ada beberapa simpulan yang dapat diambil dari penelitian ini, yaitu:

a. Model penelitian ini sangat andal dalam memprediksi pengaruh kredibilitas selebriti terhadap minat beli konsumen, dengan Sikap Terhadap Iklan sebagai vareabel antara. Hal ini ditandai dengan nilai $\chi^{2}$ sebesar 0,80 dengan probabilitas $84,9 \%$, nilai RMSEA mendekati 0 (nol) dan nilai GFI, AGFI, serta CFI masingmasing sebesar 1 (satu), dan, nilai ECVI yang lebih rendah dari pada ECVI for the saturated model.

b. Dari tiga dimensi kredibilitas selebriti, hanya Attractiveness yang pengaruhnya terhadap Sikap Terdap Iklan tidak signifikan, sedangkan Trustworthiness dan Expertise berpengaruh secara signifikan. Ketiga dimensi tersebut mempunyai kontribusi cukup besar dalam menjelaskan perubahan Sikap Terhadap Iklan. Peran ini ditunjukkan oleh koefisien determinasi $\left(\mathrm{R}^{2}\right)$ yang cukup besar yaitu $56 \%$. c. Sikap Terhadap Iklan signifikan dalam meningkatkan Minat Beli responden. Namun koefisien determinasi $\left(\mathrm{R}^{2}\right)$ yang sangat rendah menunjukkan bahwa peran Sikap Terhadap Iklan sangat lemah dalam mendorong Minat Beli responden. Hal ini diperkuat oleh fakta yang menunjukkan bahwa responden lebih mempertimbangkan citra merek/korporasi dari pada citra selebriti dalam memutuskan pembelian.

\section{Implikasi}

Penelitian ini mempunyai implikasi baik secara teoritik maupun managerial yang dapat dijelaskan sebagai berikut:

a. Penelitian ini membuktikan selebriti mempunyai peran yang sangat penting dalam meningkatkan efektifitas iklan yang diluncurkan persahaan. Temuan penelitian konsisten dengan penelitian sebelumnya seperti Goldsmith et. al. (2000), Johnston (2001), dan Ohanian (1991). Secara teoritik, konsistensi temuan ini menunjukkan kemapanan (robustness) peran kredbilitas selebriti dalam meningkatkan minat beli konsumen.

b. Bagi praktisi pemasaran, penelitian ini dapat memberikan gambaran pemahaman tentang pengaruh selebriti dalam meningkatkan efektifitas iklan. Hasil penelitian ini menunjukkan bahwa Trustworthiness dan Expertise merupakan factor yang sangat penting dalam memilih selebriti sebagai bintang iklan produknya. Meskipun selebriti yang dipilihnya tidak mempunyai daya pikat (Attractiveness) fisik yang terlalu bagus, selama selebriti tersebut mempunyai nilai Trustworthiness dan Expertise maka konsumen akan menganggap bahwa produk yang diklankan adalah produk atau merek yang kredibel. Selain itu, penelitian ini juga membuktikan bahwa Sikap Terhadap Iklan bu- 
kanlah satu-satunya vareabel yang berpengaruh terhadap Minat Beli. Responden penelitian ini menyatakan bahwa mereka lebih mempertimbangkan citra merek atau korporasi dari pada citra selebriti dalam iklan dalam memutuskan pembelian. Hal ini mensinyalkan bahwa pembiayaan yang besar untuk selebriti tidak akan meningkatkan minat beli jika merek atau perusahaan tidak mempunyai citra yang baik dibenak konsumennya.

\section{Keterbatasan Penelitian}

Penelitian ini mempunyai beberapa kelemahan yang perlu diatasi bagi peneliti yang tertarik untuk menguji efektifitas selebriti dalam iklan. Kelemahan tersebut antara lain meliputi:

a. Model yang dikembangkan sangat sederhana sehingga dapat dikatakan terlalu menyederhanakan realita yang sebenarnya. Oleh karena itu penelitian ke depan perlu memasukkan beberapa tambahan vareabel, antara lain seperti citra merek, dan citra korporasi.

b. Penelitian ini hanya menganalisa iklan yang menggunakan selebriti dengan asumsi bahwa iklan tersebut akan lebih efektif dari pada yang menggunakan bintang iklan yang berasal dari nonselebriti. Penelitian di masa yang akan datang perlu membandingkan antara penggunaan selebriti dan non-selebriti dalam mengevaluasi efektifitas iklan.

c. Penelitian ini tidak mempertimbangkan tingkat keterlibatan konsumen dalam pengambilan keputusan pembelian. Oleh karena itu, penelitian ke depan perlu memasukkan unsur tingkat keterlibatan ini untuk mengetahui apakah penggunaan selebriti dalam iklan tersebut efektif untuk produk yang dibeli dengan tingkat keterlibatan rendah atau tinggi atau kedua-duanya.

\section{DAFTAR PUSTAKA}

Alperstein, Neil M. (1991). Imaginary Social Relationships with Celebrities Appearing in Television Commercials. Journal of Broadcasting and Electronic Media, 35 (winter), (1), pp. 43-58.

Avery, Rosemary (1998). Persuasive Communication.

http://www.tristate.edu/faculty/herb ig/imc06.htm

Belk, Russel (1985). Theoretical Issues in the Intention/Behavior Discrepancy, Research and Consumer Behavior; 1; 1-34.

Biehal, Gabriel, Stephen, Debra, and Curlo, Eleonora (1992). Attitude Toward the Ad Brand Choice, Journal of Advertising, 21 (3), 19-36.

Bosnjak, Michael, Obermeir, Dirk, and Tuten, Tracy L. (2006). Predicting and explaining the propensity to bid in online auctions: A comparison of two action-theoretical models, Journal of Consumer Behavior; 5 (2), 102-116.

Daneshvary, Rennae, and Schwer, R. Keith (2000). The Association Endorsement and Consumer's Intention to Purchase. The Journal of Consumer Marketing, 17 (3), 203-213.

Datta, Palto R. (2003). The Determinants of Brand Loyalty. Journal of American Academy of Business, 3 (September), 138.

Fazekas, Anna, Senn, Charlene Y., and Ledgerwood, David M. (2001). Predictors of Intention to Use Condoms Among University Women: An Aplication and Extention of The Theory of Planned Behavior, 
Canadian Journal of Behavioural Science, 33 (2), 103-117.

Fishbein, M., and Ajzen, I. (1975). Belief, attitude, intention and behavior: an introduction to theory and research, Reading, MA; Addison-Wesley; in Trafimov, David and Duran, Anne (1998), Some tests of the distinction between attitude and perceived behavioral control, The British of Journal of Social Psychology, 37 (3), 1-14.

Goldberg, Marvin E., and Hartwick, John (1990). The Effects of Advertiser Reputation and Extremity of Advertising Claim on Advertising Effectiveness, Journal of Consumer Behavior, 17 (9), 172-179.

Goldsmith, Ronald E., Lafferty, Barbara A., and Newell, Stephen J. (2000). The Impact of Corporate Credibility and Celebrity Credibility on Consumer Reaction to Advertisements and Brands. Journal of Advertising, 29 (Fall) (3), 43-54.

Guiltinan, Joseph P., Paul, Gordon W., and Madden, Thomas J. (1997). Marketing Management Strategies and Programs, $6^{\text {th }} e d$., New York: The McGraw-Hill Companies Inc.

Holmes-Smith, P. and Rowe, K. J. (1994). The Development and Use of Congeneric Measurement Models in School Effectiveness Research: Improving the Reliability and Validity Composite and Latent Variables for Fitting Multilevel and Structural Equation Models. Paper presented in The International Congress for School Effectiveness and Improvement. Melbourne.

Hsu, Chung-kue, and McDonald, Daniella (2002). An Examination on Multi- ple Celebrity Endorsers in Advertising. Journal of Product \& Brand Management, 11 (1), 19-29.

Johnston, Russ. (2001). Credibility and Celebrity Endorsements. http://www.ciadvertising.org/stude nt_account/fall_01/adv382j/russj/ce lebrity.html

Joreskog, K. and Sorbom, D. (1996a). LISREL 8: User's Reference Guide. Chicago: Scientific Software International, Inc.

(1996b). PRELIS 2: User's Reference Guide. Chicago: Scientific Software International, Inc.

Joshi, Sangita (2003). Face Value: A Celebrity is Used to Impart Credibility and Aspirational values to a Brand but the Celebrity Needs to Match the Product. Business line. Chennai, April 24, 2003, 1.

Kahle, L.R., and Homer, P.M. (1985). Physical Attractiveness of the Celebrity Endorser: A Social Adaptation Perspective. Journal of Consumer Research, 11, March, 954961.

Kalra, Ajay, and Goodstein, Ronald C. (1998). The Impact of Advertising Positioning Strategies on Consumer Price Sensitivity. Journal of Marketing Research, 35 (2), 210-215.

Kamins, Michael A. (1989). Celebrity and Non-Celebrity Advertising in a Two-Sided Context. Journal of Advertising Research, (June/July), 3442.

(1990). An Investigation into the Match-UP Hypothesis in Celebrity Advertising: when Beauty May be Only Skin Deep. Journal of Advertising, 19 (1), 4-13. 
, Brand, M. J., Hoeke, S. A., and Moe, J. C. (1989). Two-Sided Versus One-Sided Celebrity Endorsements: The Impact on Advertising Effectiveness and Credibility. Journal of Advertising, 18 (2), 410.

Lafferty, Barbara A and Goldsmith, Ronald E. (1999). Corporate Credibility's Role in Consumers Attitudes and Purchase Intensions When a High Versus a Low Credibility Endorser Is Used in the Ad, Journal of Business Research; 44: 109-116.

Louie, Therese A., and Obermiller, Carl (2002). Consumer Response to a Firm's Endorser (Dis) Association Decisions. Journal of Advertising, (31) (winter), (4), 41-52.

Mehta, A., and Purvis, S.C. (1994). Evaluating Advertising Effectiveness through Advertising Response Modeling (ARM). Advertising and Consumer Psychology Conference. Minneapolis.

Menon, Mohan K., Boone, Louis E., and Rogers, Hudson P. (2001). Celebrity Advertising: An Assessment of Its Relative Effectiveness. http://www.sbaer.uca.edu/research/ 2001/sma/01 sma018.html.

Ohanian, Roobina (1990). Construction and Validation of a Scale to Measure Celebrity Endorsers' Perceived Expertise, Trustworthiness, and Attractiveness. Journal of Advertising, 19 (3), 39-52.

Ohanian, Roobina (1991). The Impact of Celebrity Spokespersons' Perceived Image on Consumers' Intention to Purchase. Journal of Advertising Research, (February/March), 46-54.
O’Mahony, Sheila and Meenaghan, Tony. (1997/1998). The Impact of Celebrity Endorsement on Consumers. Irish Marketing Review, 10 (2), 1524

Patzer, G.L. (1983). Source Credibility as a Function of Communicator Physical Attractiveness. Journal of Business Research, 11: 229-241.

Rex, Megan (1997). Source Expertise and Attractiveness of Celebrity Endorsers: a Literature Review. Cyber Journal of Sport Marketing, Issn. 1327-6816.

Sinar Harapan (2002). Bintang Iklan Tingkatkan Penjualan Produk. http://www.sinarharapan.co.id/ekon omi/promarketing/lalu.html

Solomon, Michael R., Ashmore, Richard D., and Longo, Laura C. (1992). The Beauty Match-Up Hypothesis: Congruence between Types of Beauty and Product Images in Advertising. Journal of Advertising, (21) (December), (4), pp. 23-34.

Stafford, Marla R., Stafford, Thomas F., and Day, Ellen (2002). A Contingency Approach: The Effects of spokesperson Type and Service Type on Service Advertising Perceptions. Journal of Advertising, 31 (2), 1734.

Terhune, Chad, and Steinberg, Brian (2003). Coca-Cola Signs NBA Wunderkind; LeBron James's Deal to Sell Sprite Comes as Woes Beset Current Pitchman Bryant. Wall Street Journal, Eastern ed., August 22, B5.

Till, Brian D. (1998). Using Celebrity Endorsers effectively: Lessons from Associative Learning. The Journal 
of Product and Brand Management, 7 (5), 400.

Tom, G., Clark, R., Elmer, L., Grech, E., Masetti Jr. J., and Sandhar, H. (1992). The Use of Created versus Celebrity Spokespersons in Advertisements. The Journal of Consumer Marketing, 19 (4), 45-51.
Walker, Mary, Langmeyer, Lynn, and Langmeyer, Daniel (1992). Celebrity Endorsers: Do You Get What You Pay For? The Journal of Consumer Marketing, 9 (2), 69-76.

Wheeler, Robert (2003). Choosing Celebrity Endorsers: Tips and Traps. Nonprofit World. 21 (4), 17. 